\title{
Weichselian phases and ice dynamics of the Scandinavian Ice Sheet in northeast Germany: a reassessment based on geochronological and geomorphological investigations in Brandenburg
}

\author{
Jacob Hardt \\ Fachbereich Geowissenschaften, Physische Geographie, Freie Universität Berlin, Berlin, Germany \\ Correspondence: Jacob Hardt (jacob.hardt@fu-berlin.de) \\ Relevant dates: $\quad$ Published: 21 December 2017
}

How to cite: Hardt, J.: Weichselian phases and ice dynamics of the Scandinavian Ice Sheet in northeast Germany: a reassessment based on geochronological and geomorphological investigations in Brandenburg, E\&G Quaternary Sci. J., 66, 101-102, https://doi.org/10.5194/egqsj-66-101-2017, 2017.

Supervisors: Margot Böse, Markus Fuchs,

Christopher Lüthgens

Dissertation online:

http://www.diss.fu-berlin.de/diss/receive/FUDISS_thesis_ 000000104286

This thesis presents new geochronological and geomorphological data concerning Weichselian ice dynamics of the Scandinavian Ice Sheet for the northeast German lowland area. The largest Weichselian ice extent in Brandenburg (Brandenburg phase) occurred in the late marine isotope stage 3. The global Last Glacial Maximum is represented by the Pomeranian ice marginal position in Brandenburg ( $\sim 20 \mathrm{ka}$ ). Therefore, a 2-fold Last Glacial Maximum in Brandenburg, as previously proposed by Lüthgens and Böse (2011), is confirmed.

For the first time, we determined optically stimulated luminescence (OSL) ages of glaciofluvial deposits associated with the Weichselian Frankfurt phase at a site in Ladeburg (central Brandenburg; Fig. 1). Furthermore, we report new OSL ages of glaciofluvial deposits from the lignite mine Jänschwalde (southern Brandenburg), a key site regarding the Weichselian maximum extent during the Brandenburg phase. In combination with cosmogenic nuclide surface exposure ages of glacigenic boulders, which were collected from liter- ature and recalibrated with an updated ${ }^{10} \mathrm{Be}$ production rate, a consistent process-based model of the Weichselian ice dynamics in Brandenburg was developed (Fig. 1).

The ice advance of the Brandenburg phase was dated to $34.1 \pm 4.6 \mathrm{ka}$. For the formation of the Brandenburg ice marginal position, a mean age of $30 \pm 4 \mathrm{ka}$ was determined at Jänschwalde. The succeeding meltdown during the so-called Frankfurt phase was dated to $26.3 \pm 3.7 \mathrm{ka}$ at Ladeburg. The subsequent landscape stabilization phase started at around $24 \pm 2 \mathrm{ka}$ in central Brandenburg, which was deduced by recalibrated exposure ages of glacigenic boulders (Hardt et al., 2016). These ages are corroborated by other published OSL ages from the region (Fig. 1).

The recalibration of previously published cosmogenic exposure ages from glacigenic boulders with an up-to-date ${ }^{10} \mathrm{Be}$ production rate (Heyman, 2014) resulted in a considerable increase of the ages (9-15\%; Hardt and Böse, 2017). In combination, the OSL ages and the cosmogenic nuclide exposure ages now provide a consistent geochronology of the Weichselian ice dynamics in Brandenburg. The largest Weichselian ice extent during the late marine isotope stage 3 (Brandenburg phase) corresponds with the so-called Klintholm advance in Denmark (Houmark-Nielsen, 2010) and a possible ice advance in central Poland (Marks, 2012). 


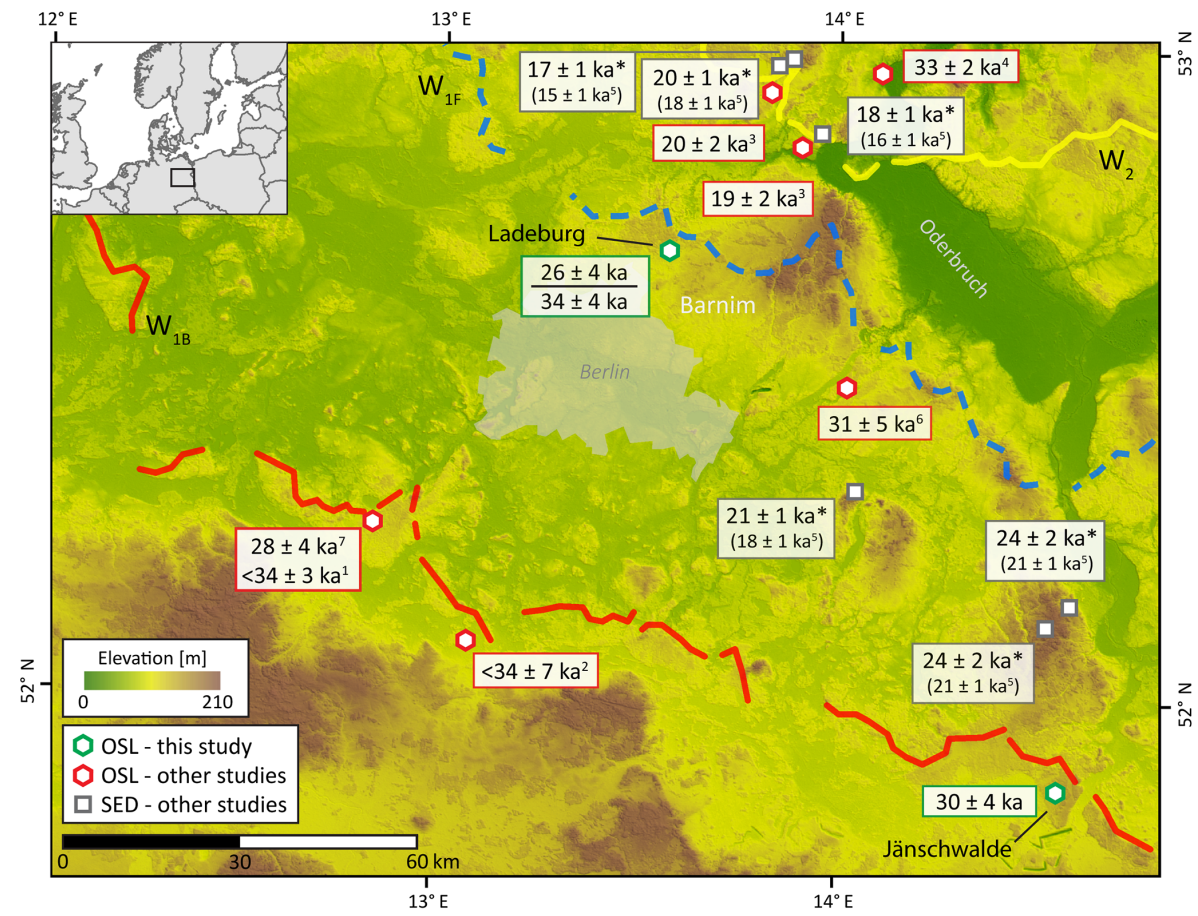

Figure 1. Overview map showing compiled ages from the thesis (green) and other authors (red/grey). OSL is optically stimulated luminescence dating. SED is cosmogenic nuclide surface exposure dating. Figure modified from Hardt et al. (2016) and references therein. See the respective paper and the thesis for a detailed list of the cited ages.

In the area of the supposed Frankfurt ice marginal position on the Barnim plateau (a till plain to the north of Berlin), we detected a series of ice marginal fans by analysis of a highresolution lidar (light detection and ranging) digital elevation model. These arcuate, parallel landforms rise up to $10 \mathrm{~m}$ from the surroundings and extend up to $15 \mathrm{~km}$ in length and up to $1.5 \mathrm{~km}$ in width. Outcrop studies, geophysical investigations (electrical resistivity tomography) and map interpretation revealed that the ice marginal fans consist of diamictic material (Hardt et al., 2015). OSL dating of glaciofluvial deposits beneath and above one of the structures revealed that their formation took place in the Frankfurt phase $(26 \pm 4 \mathrm{ka}$; Hardt et al., 2016), during the successional downwasting of the ice after the Brandenburg phase.

Data availability. The data are publicly available via the thesis and the references therein.

Competing interests. The author declares that he has no conflict of interest.

\section{References}

Hardt, J. and Böse, M.: The timing of the Weichselian Pomeranian ice marginal position south of the Baltic Sea: A critical review of morphological and geochronological results, Quatern. Int., in press, 2017.

Hardt, J., Hebenstreit, R., Lüthgens, C., and Böse, M.: Highresolution mapping of ice-marginal landforms in the Barnim region, northeast Germany, Geomorphology, 250, 41-52, 2015.

Hardt, J., Lüthgens, C., Hebenstreit, R., and Böse, M.: Geochronological (OSL) and geomorphological investigations at the presumed Frankfurt ice marginal position in northeast Germany, Quaternary Sci. Rev., 154, 85-99, 2016.

Heyman, J.: Paleoglaciation of the Tibetan Plateau and surrounding mountains based on exposure ages and ELA depression estimates, Quaternary Sci. Rev., 91, 30-41, 2014.

Houmark-Nielsen, M.: Extent, age and dynamics of Marine Isotope Stage 3 glaciations in the southwestern Baltic Basin, Boreas, 39, 343-359, 2010.

Lüthgens, C. and Böse, M.: Chronology of Weichselian main ice marginal positions in north-eastern Germany, E\&G Quaternary Sci. J., 60, 236-247, 2011.

Marks, L.: Timing of the Late Vistulian (Weichselian) glacial phases in Poland, Quaternary Sci. Rev., 44, 81-88, 2012. 